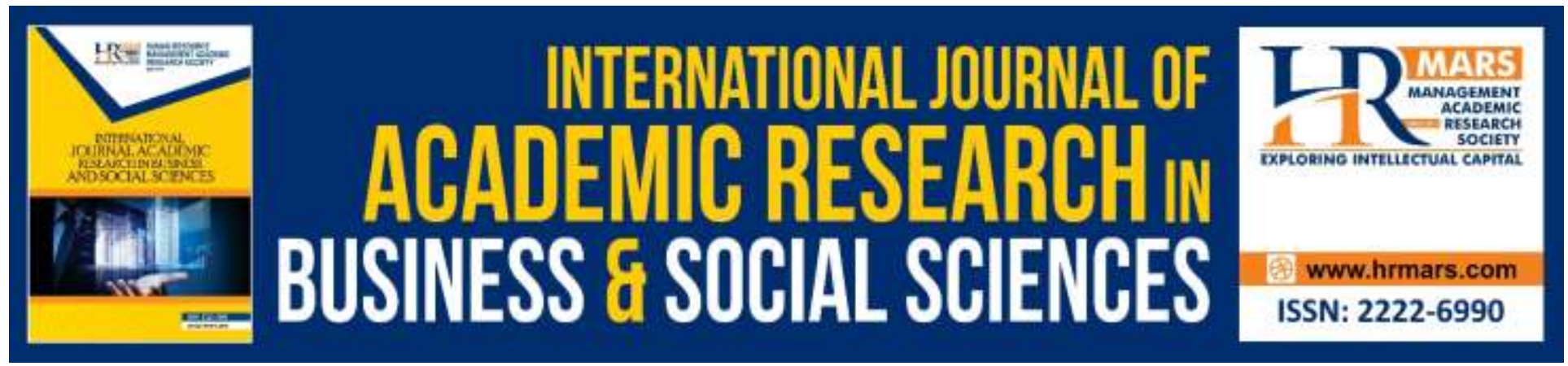

\title{
Firms Attributes and Audit Fees in Nigeria Quoted Firms
}

\section{Ohidoa, T \& Okun, O. Omokhudu}

To Link this Article: http://dx.doi.org/10.6007/IJARBSS/v8-i3/4004

DOI: $10.6007 /$ IJARBSS/v8-i3/4004

Received: 03 Mar 2018, Revised: 26 Mar 2018, Accepted: 30 Mar 2018

Published Online: 09 April 2018

In-Text Citation: (Ohidoa \& Okun, 2018)

To Cite this Article: Ohidoa, T., \& Okun, O. O. (2018). Firms Attributes and Audit Fees in Nigeria Quoted Firms. International Journal of Academic Research in Business and Social Sciences, 8(3), 711-725.

Copyright: (C) 2018 The Author(s)

Published by Human Resource Management Academic Research Society (www.hrmars.com)

This article is published under the Creative Commons Attribution (CC BY 4.0) license. Anyone may reproduce, distribute, translate and create derivative works of this article (for both commercial and non-commercial purposes), subject to full attribution to the original publication and authors. The full terms of this license may be seen

at: http://creativecommons.org/licences/by/4.0/legalcode

Vol. 8, No. 3, March 2018, Pg. $711-725$

http://hrmars.com/index.php/pages/detail/IJARBSS

JOURNAL HOMEPAGE

Full Terms \& Conditions of access and use can be found at http://hrmars.com/index.php/pages/detail/publication-ethics 


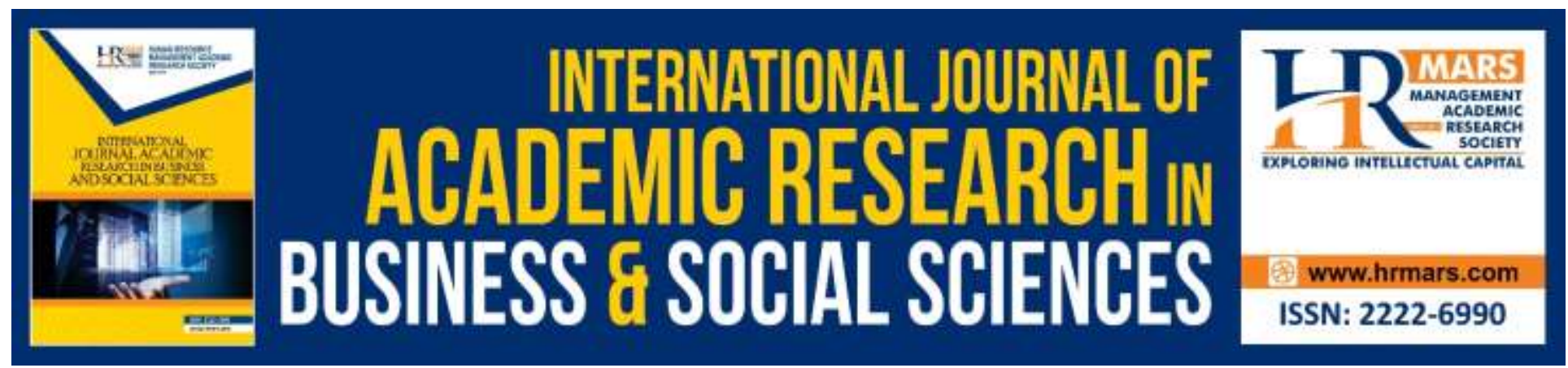

\title{
Firms Attributes and Audit Fees in Nigeria Quoted Firms
}

\author{
Ohidoa, T \\ Department of Accounting, Faculty of Management Sciences, University of Benin, Benin City. \\ Email: evetolambassador@gmail.com
}

\section{Okun, O. Omokhudu}

Department of Accounting, University of Benin, Benin City

Email: okun.omokhudu@uniben.edu

\begin{abstract}
This study examined the firms' characteristics and audit fees in Nigeria. The justification arose from the fact that, auditing profession has come under increased scrutiny over the years about the growing amount of fees paid by audit client and the contributing impact of such fees on auditor independence and the need to investigate the firms' factors that affect audit fees in Nigeria. The study employed a employed time series and cross-session data (panel data) of firms listed at the Nigeria Stock Exchange and data used was gathered from secondary source (annual financial statement) of firms quoted at the Nigeria Stock Exchange from 2013-2017. A sample size of eighty-nine (89) firms was used through the aid of Yaro, (1964) formula for sample size determination. And the statistical tool used in the study was Panel Least Square Regression with the aid of Eview 7.0 and SPSS 20. The study found that, auditor type, client's firm size, client's complexity, client's firm risk and audit committee independence have significant effect on audit fees, while firm's profitability has no effect on audit fees. The study recommended that, further academic researchers should employ more corporate governance variables on audit fees and period covered should fall between six to seven years for the purpose of analyzing the data. Similarly, future researchers in relation to this study should equally cover a period of six to seven years using the same panel least square or any other related statistical tool.
\end{abstract}

Keywords: Audit fees, Client Size, Auditor's Size, Client Complexity, Auditees.

\section{Introduction}

Auditing is a fundamental concept in accountancy profession. The amount charged by the professional accounting firm has attracted a great deal of concern among academic researchers and practitioners. International Standards on Auditing No.15 (2011), audit fees are the amount paid to financial auditors for the certification of financial statements. In other words, audit fees 
can be defined as the amounts of fees (wages) charged by the auditor for an audit task performed on the accounts of an enterprise (auditee). The determination of the audit fees is based on the contract between the auditor and the enterprise in accordance with time spent on the audit process, and the service required (Simunic, 1980). There is a growing trend in accounting in recent years about the issue of audit fees relating to how auditors determine the amount of fees charged for audit services. This is a fundamental issue that needs to be investigated empirically for clarity. The full separation between ownership and management demands the need for appointment of an auditor charged with the responsibility of examining the financial statements prepared by client's management. The fee to be charged by the auditor for service or engagement within a given duration is very fundamental in auditing service. The audit fees and conditions of services boil down on the meeting of minds between the auditor and the client (Hayes et al. 2005). The auditing profession has come under increased scrutiny over the years about the growing amount of fees paid by audit client and the contributing impact of such fees on auditor independence (Geiger, \& Papanatasiou, 2006; Geiger \& Rama, 2003; Basioudis). The necessity for this study rise from the fact that very few studies have considered the audit fees determinants from the perspective of auditees, corporate governance and auditing firm attributes.

Therefore, in the light of the above, the research questions that drive this study are stated as follow: To what extent does audit firm's size affect audit fees; to what degree does client firm's size affect audit fees; what is the effect of client's firm profitability on audit fees; what impact does clients' risk have on audit fees; to what extent does client firms' complexity affect audit fees; and does audit committee independence has effect on audit fees?

\section{Literature Review Conceptual Framework on Audit Fees}

Auditing as a concept is fundamental to the profession accountancy. The amount charged by the practitioner accountant (auditor) has attracted a great serious concern among academic researchers, practitioners and other stakeholders. Auditing as a process entails performing procedures to obtain evidence about amount disclosure in the financial statement of organizations so as to evaluate the appropriateness of accounting statement of accounting estimates made by management (American International Certified Public Accountant, 2009). In essence, audit fees charged by the auditors are very important in the performance of an audit task. The manner in which auditors are remunerated in corporate organizations in Nigeria is a vital issue (CAMA, 2004). AICPA (2009), see audit fees as sums payable to the auditor for the audit services offered to the auditee. Audit firms have to consider cautiously cost and benefit that will arise from the discharge of their services to decide their audit fees, the aspects regarding audit fees are extensively analyzed from point of view of the effects the different fees levels may have on the auditors' independence. The audit fees can thus be simply defined as sum paid to the auditor, for the audit services offered to the auditees. In this respect, code of Ethics for Professional Accountants of International Federations of Accountants (IFAC, 2010) established that "when entering into negotiations regarding professional services, a professional accountant in public practice may quote whatever fee is deemed appropriate" (Section 240). 


\section{Audit Firm's Size and Audit Fees}

Audit firm size is an important aspect of the audit firm characteristics that affect the audit fees charged by the auditor. The Auditor Size is frequently measured based on the company's assets, market share and the number of employees. Choi, Kim, K. \& Zang, (2010), investigate the relationship between office size, audit quality and audit pricing, they assert that, office size is positively associated with audit quality, and that large offices attracts higher audit fees and provide higher quality audits. Similarly in this same direction, Francis, 1984; and Palmrose, 1988, explained the existence of a strong relationship between audit fees and audit firm size. Prior studies Simon, Teo \& Trompeter (1992) found that clients pay more to the international big firms due to their Brand name and the higher audit quality provided. The Big Eight or Big Five, now the Big Four (Ernst \& Young, Deloitte, PricewaterhouseCoopers (PWC) and KPMG) audit firms receive premium fees in many countries compared to non-Big Four (Palmrose, 1988). As a result of the financial strength and expertise that these firms have, they are able to provide higher quality audit. This assertion is also supported by numbers of important study in the United States of America market (DeAngelo, 1981). Therefore, based on these prior studies, auditor's size is included in our model; to examine its effect on audit fees in Nigeria context. $\mathrm{Ho}_{1}$ : Audit firm size does not affect audit fees.

\section{Client's Firm Size and Audit Fees}

Based on Carson, Farglier, Simon \& Tylor (2004), it can be concluded that, the client size is the most important factor that influences audit fees, it is usually measured by total assets, revenues, sales and number of employees of the Client Firm. The size of the client has a direct impact on the auditors' work, and the time spent in the auditing process. Larger enterprises required more audit services than smaller enterprises; hence, it is expected that these large clients pay higher fees in relative to smaller clients in the same industry (Palmrose, 1986; Carson, Fargher, Simon \& Taylor, 2004). Hence, there is a positive relationship between audit fees and client size. (Simunic, 1980; Low et al., 1990; Chan et al., 1993; \& Carson, et al., 2004). Obviously, auditing small client and auditing large client will require different time and efforts which will invariably attract different level of audit fees. A financial audit involves the scrutiny of the accounting, the internal control system, and the financial transactions etc of the client's enterprise. Larger organizations will usually undertake more voluminous transactions than the smaller and medium sized firms. To these assertions, Joshi and Bastaki, (2000); Rubin, (1988); Gonthier-Besacier and Schatt (2007), supported the assumption that client's business scope has a positive correlation with the amount of audit fees charged by auditor.

Another prominent study in this context is that of Che-Ahmad and Houghton, (1996), who after using a matched-pair sampling method in their study of the influence of auditor size, firm complexity, and firm's risk (firm characteristics) on audit fees, assert the existence of a positive relationship between the variables. This same assertion was also reaffirmed in the study of O'Sullivan (2009), that a relationship exists between firms' risk, clients' complexity and audit fees. In this same vein, Semiu and Olayinka, (2010) used firms' size as a variable in their study and also assert that there is strong relationship between enterprise size and audit fees. On the contrary, Carson et al (2004) using Australian audit fee data for the period of 1995 to 1999 in his study came out with an assertion that there is no correlation between audit fees and client size. Therefore, in the light of the foregoing conflicts results in prior studies, we 
decided to include this variable (Client's size) in our study to examine its true effect on audit fees using Nigeria data and also, using the sales volumes of firms to proxy client's size in order to add uniqueness to our study instead of total asset predominantly used in prior studies. $\mathrm{Ho}_{2}$ : Client's firm size does not affect audit fees charged by auditor.

\section{Client's Firm Profitability and Audit Fees}

The client's firm profitability is considered as an important indicator of management performance and its efficiency in allocating available resources. The enterprise profitability can be known by finding the income or loss figure shown in the income statement (Firth, 1985; Simon et al. 1986; Chung \& Lindsay, 1988; Low et al., 1990; Waresulkarim \& Moizer, 1996). There are many profitability ratios that can be used to measure client profitability, such as, return on asset, return on equity, return on capital employed etc. Firms reporting high level of profits will naturally be subject to precise audit testing of their revenue and expenses and this will result in high audit fees (Joshi \& Al-Bastaki, 2000; Sandra \& Patrick, 1996). The relationship between audit fees and profitability can be positive and negative, some have argued that firms reporting high level of profit are subject to rigorous audit testing to related revenue and expenses and this entails more fees (Joshi, et al., 2000). Others make the point that underperforming firms' are more likely to control their overheads and this would result in less audit work (Chem et al., 2002). Nevertheless, it must be noted that costs reduction may result in reduced internal control and engender more audit control. HO2: there is no significant relationship between clients' firm profitability and audit fees.

\section{Client's Firm Risk and Audit Fees}

The influence of auditees risk on audit fees has been examined by many previous researchers (Simunic's, 1980; Turpen, 1990; Semiu and Olayinka, 2010; AICPA 2012). Client's risk is considered an important factor that influences audit fees. Audit risk measures the odds of an auditor issuing an unqualified judgment on materially misstated financial statements Sandra and Patrick (1996), used gearing (clients' debt ratio) and liquidity ratios to determine the client's risk. The audit risk can be calculated by the following ratios: current asset/ total assets, treasury, long-term debt/ total assets, income before tax/ total assets (Carson et al., 2004; Joshi \& Al-Bastaki, 2002). The most preferred risk measure is the debt ratio. It is defined as the percentage of long-term debt to total assets. It measures the firm's ability to pay off its incurred debt. In this case, if the debt ratio is relatively high, the long-term financial structure of the client's company will be unstable, and the company may not be able to pay off its debt in a proper behaviour which may lead to a lower credit rating.

In general, risk is higher for firms that have endured financial losses, leading to higher possibility of bankruptcy and therefore, high probability of legal actions against both the client and the auditor. Auditors need to do more work to reduce any potential litigation against them; the more the work and time needed to accomplish the auditing process, the greater the audit fee is. Therefore, Audit fees are positively associated with the Clients' risk (Simon et al., 1987; Craswell \& Francis, 1999). Based on the assertions above, we include this variable (audit risk) in this study to know if same result will be replicated or not using data from the annual reports of firms instead of using questionnaire. Ho4: Clients' firm risk does not have impact on audit fees. 


\section{Client's Firm Complexity and Audit Fees}

Complexity of the auditees can be measured by the number of branches and subsidiaries of the firm locally and internationally. Sandra and Patrick (1996), assert that, the more complex the client firm is, the greater the number and the more diversified the subsidiaries and operations are; which necessitate more audit work leading to a higher audit fees. Auditors of high complex firms often charge high audit fees in examining and evaluating the firm's financial statements. Sandra and Patrick (1996), foreign subsidiaries have to abide by a variety of legislative and proficient requirements for disclosure, which necessitate further audit testing, requiring more time and additional manpower to complete the audit process. This implies that, the companies have to bear additional charges for audit work.

Therefore, client's complexity has a positive correlation with the audit fees (Simunic, 1980; Low et al., 1990; Chan et al., 1993; Firth, 1997; Carson, et al 2004). Complexity of audited firm is commonly examined in two aspects; that is complexity of operations and complexity of the financial statements composition. Consequently, the complexity of operations of the enterprise may lead to Complex transactions which will invariably require an auditor spending longer time and other resources in carrying out an audit task, and the consequence of this is high audit fees. In particular, Joshi and Al-Bastaki (2000) have shown that audit fees are positively associated with the number of subsidiaries in foreign countries. To buttress this assertion further, Simunic, 1980; Francis, 1988; Gonthier-Besacier and Schatt 2007; and Semiu and Olayinka (2010) find considerable evidences that suggest a positive association of firms' complexity and audit fees. To investigate the truism of this assertions and inference, we decide to add this variable in this study. $\mathrm{Ho}_{5}$ : Clients' firm complexity does not have effect on audit fees.

\section{Audit Committee Independence and Audit Fees}

Based on the role of audit committee, Collier and Gregory (1996) argued that audit committees independence may have effect on audit fees in two opposite ways. The first is to enhance audit quality, audit committee may require more work done by external auditors and hence, may put pressure on the company to pay higher audit fees. The second is since audit committee independence can strengthen internal control systems, audit procedures may increase and thus audit fees will decrease. The auditors discovered that in the UK, the existence of audit committee independence has a positive and significant effect on audit fees; in contrast, Ho and Hutchinson (2010), find that in Hongkong, auditors expect that the presence of audit committee independence lower audit risk, thereby leading to lower audit fee charged.

Nevertheless, Goddard and Masters (2000) investigate that the existence of audit committee independence in the UK's companies has no relationship with the amount of audit fees. Also, to the above assertions, Steward and Munro (2007), state that Australian external auditor relies on an effective internal control but do not reduce their audit testing. Moreover, time and effort saved due to the presence of effective internal control balance with time spend for more meetings with client managers and partners and so, it has no significant relationship with audit committee independence (Steward and Munron, 2007). It is upon this background of conflicting literatures, we decide to include this variable in our model to ascertain its effect on audit fees using Nigeria data. $\mathrm{Ho}_{6}$ : there is no significant relationship between audit committee independence and the audit fees. 


\section{Methodology}

The study employed time series and cross-session data (panel data) of firms listed at the Nigeria Stock Exchange, covering time period of five (5) years (2013-2017). The variables that are captured include Audit fees, Audit's Firm size, Client's Firm Size, Audit Client's Firm Profitability, Client's Firm Risk, Client's firm complexity and Audit committee independence. The firms to be investigated comprise listed firms in the Nigeria Stock Exchange. A total of two hundred and nine (209) firms quoted in the Nigeria Stock Exchange constitute the population of the study (Fact book, 2017). The firms cut across those in the manufacturing sector such as brewery, bottling, conglomerate, building materials, health care, Construction and agriculture etc and those in the financial sector like the banks and insurance firms.

The sample for this study is eighty-nine (89). The basis for the arrival of the sample is by adoption of (Yaro, 1964) formula widely used for sample size determination in the field of research. The formula is stated as: $n=N / 1+N(e) 2$. Where, $N=$ Population, $n=$ Sample Size and e $=$ Level of Significant (error term). That is, $n=209 / 1+209(0.08) 2=89$. The rationale behind eight percent $(8 \%)$ used as our level of significant is because, it gives a reasonable sample size of 89 firms for this study, and a reduction below this will lead to a lesser sample which may not be too good compare to our population of study. The study basically employed secondary source of data collection. Historical data were obtained from the annual financial reports of accounts of sampled firms listed in the Nigeria Stock Exchange. The model for this study is adapted from Simunic, (1980) model. The reason for our choice of this model is based on the fact that, Simunic's model used so far in most studies in Africa and beyond, to test the effect of firms' attributes and audit fees, has produced consistent results. The model includes the following parameters:

\section{audfee $=x 0+x 1$ firmsize $+x 2$ firmcomp $+x 3$ firmrsk $+x 5$ firmtype $+\varepsilon$.}

Where, Audfee $=$ audit fee; Firmsize $=$ Total asset of the auditee; Firmcomp $=$ Numbers of firms subsidiaries; Firmrsk = the level of firm leverage; and firm Type $=$ whether firm is public or private. In this study, our model includes variables in Simunic's model and other variables such as: audit firm size, firm's profitability, and audit committee independence, and adoption of a different measure of firm's size in order to add uniqueness to our study and also, produce a reliable and dependable result for academic and economic usefulness. Therefore, for the purpose of this study, our model is state as:

audfee $_{i t}=\alpha_{0}+\alpha_{1}$ audtype $_{i t}+\alpha_{2}$ clfirmsize $_{i t}+\alpha_{3}$ clfirmpat $_{i t}+\alpha_{4}$ clfirmrsk $_{i t}+\alpha_{5}$ clfirmcomp $_{i t}+$ $\boldsymbol{\alpha}_{6}$ audcomind $_{i t}+\boldsymbol{e}_{i t .}$ Our apriori expectation is stated as: $\alpha_{1}>0 ; \alpha_{2}>0 ; \alpha_{3}>0 ; \alpha_{4}>0 ; \alpha_{5}>0 ; \alpha_{6}>0$. Our variables are measured as: audfees = natural logarithm of audit fee paid by the client (Taylor, Simon, \& Greg (1999), $\alpha 0=$ Constant; $\alpha 1, \alpha 2, \alpha 3, \alpha 4, \alpha 5, \alpha 6=$ Unknown coefficients; audtype $=$ the type of auditor that audited the firm. If the audit firm is a BIG4 is equal to 1, otherwise 0. (Francis, 1984); clientfirmSze = firms' turnover; clientfirmpat = natural logarithm of pat (Firth, 1985); clientfirmrsk = auditees risk is measured as long term debt divided by total asset (Sandra \& Patrick, 1996); clientfirmcomp = firm complexity which is measured as number of branches and subsidiaries of the firm locally and internationally (subsidiaries in foreign countries (Sandra \& Patrick, 1996); audcomind = audit committee independent, is measure by the ratio of non-executive to executive members in the audit committee; and $e=$ error term. 
INTERNATIONAL JOURNAL OF ACADEMIC RESEARCH IN BUSINESS AND SOCIAL SCIENCES

Vol. 8, No.3, March 2018, E-ISSN: 2222-6990 @ 2018 HRMARS

Data Analysis and Interpretation of Results

Table 4.1: Descriptive statistics

\begin{tabular}{|c|l|l|l|c|c|}
\hline Variables & Mean & Maximum & Minimum & $\begin{array}{c}\text { Jarque- } \\
\text { Bera }\end{array}$ & P-Value \\
\hline AUDFEES & 25962115 & $2.43 \mathrm{E}+08$ & 350000.0 & 1235.44 & 0.0000 \\
\hline AUDTYPE & 0.6757 & 1.0000 & 0.0000 & 79.8709 & 0.0000 \\
\hline CLFSIZE & $3.13 \mathrm{E}+10$ & $3.79 \mathrm{E}+11$ & 13437000 & 2946.60 & 0.0000 \\
\hline CLFIRMPAT & $4.62 \mathrm{E}+9$ & $2.81 \mathrm{E}+11$ & -68752000 & 665073.5 & 0.0000 \\
\hline CLFIRMFRISK & 0.4599 & 2.290 & 0.0100 & 94.9623 & 0.0000 \\
\hline CLFIRMCOMP & 3.8559 & 52.0000 & 0.0000 & 14127.45 & 0.0000 \\
\hline AUDCOMIND & 0.6437 & 1.1000 & 0.0000 & 19.3840 & 0.0000 \\
\hline
\end{tabular}

SOURCE: Researcher's survey, 2013

Table 4.1 highlights descriptive statistics of the variables examined with emphasis on mean, maximum, minimum and the JarqueBera test results. It is deduced that Audit fees (AUDFEES) for the Periods investigated stood at a mean value of $\mathrm{N}-25,962115$. This is approximately at N 26 million, while the maximum and minimum auditfees stood at N 243,000,000 ( 243 Million) and $\mathrm{N} 350,000$ (N350 thousand) naira respectively, and a significant Jarque-Bera result of 1235.44, 0.000 with impressive P-value of 0.000 (less than $5 \%$ critical value). Also, Auditor type (AUDITYPE) stood at a mean value of 0.6757 which is approximately $68 \%$, indicating that about $68 \%$ of the total firms were audited by the BIG4 auditors while the $32 \%$ were by local auditors; (audit firm in Nigeria); with maximum and minimum values of 1 and 0 representing the BIG 4 and local auditors; and Jarque-Bera test shows 79.8709 and less than 5\% significant t-level. Furthermore, client's firm size (CLFSIZE) which is measured with turnover for the periods stood at a mean value of over N-313 million while the maximum and minimum turnover (CLFSIZE) stood at approximately $\mathrm{A}$ 3.79 billion and over $\mathbb{N} 13$ million respectively at a significant Jarque-Bera value of 2946.6 (PValue than 5\%). It is observed that Profit After Tax of client (PAT) of firm show a mean value of $\mathrm{N}$ 462 million, maximum and minimum value of $\mathbb{A}-281$ Billion and $-\mathbb{N}-6$ about $\mathbb{A} 7$ million reported loss, while the Jarque-Bera test statistic indicates significant value of 665073.5 . In the same vein, client's firm risk (CLFRISK) points out mean value of 0.4599 indicating at about $46 \%$ of the firms are financed with debt, with a maximum and minimum values of $2.29 \%$ and $1 \%$ respectively and the Jarque-Bera test statistic stood at $94.96 \%$ and at zero (0) P-value.

The client's firm complexity (CLFCOMP) which measured with the numbers of firm branches reveals mean value of approximately 4 branches, with maximum and minimum value of 52 branches and 0 , and Jarque-Bera test result of 14127.45 at significant level of $0 \%$. However, Audit committee independence (AUDCOMIND) which stood at a mean value of 0.6437 indicates that over $64 \%$ of the audit fees is accounted for by audit committee independence and JarqueBera result stood at a value 19.38 . The entire results were at $0 \%$ significant level less than $5 \%$ critical significant level in terms of evaluating the Jarque-Bera test. 
INTERNATIONAL JOURNAL OF ACADEMIC RESEARCH IN BUSINESS AND SOCIAL SCIENCES

Vol. 8, No.3, March 2018, E-ISSN: 2222-6990 @ 2018 HRMARS

Table 4.2: Correlation Analysis

\begin{tabular}{|c|c|c|c|c|c|c|c|}
\hline VARIABLES & AUDFEES & AUDTYPE & CLFSIZE & CLFPAT & CLFRISKK & CLFCOMP & AUDCOMIND \\
\hline AUDFEES & 1.000 & & & & & & \\
\hline AUDTYPE & .334 & 1.000 & & & & & \\
\hline CLFSIZE & .702 & .338 & 1.000 & & & & \\
\hline CLFPAT & .361 & .171 & .329 & 1.000 & & & \\
\hline CLFRISK & .406 & .231 & .289 & .188 & 1.000 & & \\
\hline CLFCOMP & .641 & .171 & .696 & .247 & .341 & 1.000 & \\
\hline AUDCOMIND & .061 & .060 & .067 & .055 & .061 & .090 & 1.000 \\
\hline
\end{tabular}

SOURCE: Researcher's survey, 2013

Table 4.2 shows associations of variables captured in the study. The association between Audit fees (AUDFEES) and the auditor type (AUDITYPE) revealed that they are positively significant at 0.334 (33\%). This implies that amount charged as audit fees is associated with the type of auditor that audited the firm. This invariably indicates that amount charge by the BIG 4 auditors like Pricewater Cooper, Ernest and Young, KPMG and Akintola Williams Deloitte (auditor with international affiliations) is quite different from what is being charged by local auditors in Nigeria. Similarly, the correlation between audit fees (AUDFEES) and client's firm size (CLFSIZE) deduce that they are positively and highly significant at a value over 702 (70\%). This suggests that the firm sizes as measured are large which as well implies that Audit fees (AUDFEES) charged is associated with the size of the firm. The amount charged (Audit fees) on a small size firm can be different from a large firm. In the same vein, Audit fees (AUDFEES) and client's firm Profit after tax (CLFPAT) are positively correlated at 0.36, meaning that when a firm makes profit after all necessary deduction and government has collected tax or the company has complied with the payment of the agreed tax can be associated with the amount to be charged as audit fees (AUDFEES).

However, it further deduce that Audit fees (AUDFEES) and client's firm risks which is the extent in which the firm is financed with debt are positively associated at Karl Pearson product movement correlation coefficient at a value of 0.406 . The implication is that a firm financed with debt (FRISK) can determine the amount to be charged as audit fees (AUDFEES) because of some intricacies and fundamental issues that would arise which would be necessary in investigating the creditor and the firm by the auditor. Consequently, Audit fees and client's firm complexity stood at Pearson positive correlation value of 0.641 which is over $64 \%$. The correlation results indicate that the extent in which a firm is complex to audit can attract more amounts charged as audit fees. The result shows high correlation value meaning that the respective firm audit fees charged are high as compared with the complexity nature of the firm audited with the stated periods under investigation.

Finally, Audit fees charged and Audit committee independence stood at positive correlation value of 0.061 . The result of the correlation between audit fees and audit committee independence (AUDCOMIND) implies that they are not significantly correlated which invariably means that whether high or low audit fees was not highly influence by the independence audit committee. Meanwhile, all the Pearson correlations of variable were positively related and $10 \%$ significance level and at 2-tailed as shown in the appendix 2. 
INTERNATIONAL JOURNAL OF ACADEMIC RESEARCH IN BUSINESS AND SOCIAL SCIENCES

Vol. 8, No.3, March 2018, E-ISSN: 2222-6990 @ 2018 HRMARS

Table 4.3: Estimation of Panel Least Square Results

\begin{tabular}{|l|c|l|l|l|}
\hline \multicolumn{2}{|c|}{ VARIABLES } & COEFFICIENT & T.STAT & P-VALU \\
\hline DEP & INDEP & & & \\
\hline \multirow{4}{*}{ AUDFEES } & C & 2.5454 & 11.9983 & 0.000 \\
\cline { 2 - 5 } & AUDTYPE & 0.0966 & 1.7582 & 0.0794 \\
\cline { 2 - 5 } & CLFSIZE & 0.0147 & 5.3790 & 0.000 \\
\cline { 2 - 5 } & CLFPAT & 0.0567 & 1.0882 & 0.2771 \\
\cline { 2 - 5 } & CLFRISK & 0.2893 & 9.0123 & 0.0000 \\
\cline { 2 - 5 } & CLFCOMP & 0.15594 & 5.9948 & 0.0000 \\
\cline { 2 - 5 } & AUDCOMIND & 0.2056 & 5.2059 & 0.0000 \\
\hline
\end{tabular}

SOURCE: Researcher's survey, 2013

AUDFEES $=2.55+0.97$ AUDTYPE+0.015CLFSIZE+0.057CLFPAT+0.29CLFRISK+ 0.16CLFCOMP + 0.21AUDCOMIND

(12.00) (1.758)

(1.09)

(9.012)

(5.99)

$R^{2}=0.7206, R^{2}=0.7142$, S.E of regression $=0.3275$, F-statistic $=111.68(0.0000), D W=2.2615$. - Table 4.3 reveals extract of the outcome of the panel least square regression presenting the results of the coefficients t-stat and P-values. Reported in parentheses are the t-statistics values of the independent variables as against the dependent variable. The coefficients of the independent variables on the dependent variable (Audit fees) are analysed accordingly as follows. As for Auditor type (AUDTYPE) with a positive coefficient value of 0.0966 with Audit fees, implies that a unit changes in the type of auditor that audits the firm will lead to about $10 \%$ change in the amount charged as Audit fees by the auditor on its client. It is also noted that client's firm size (CLFSIZE) which stood at a positive coefficient value of 0.0147 with audit fees, indicates that a unit increase in the size of the firm would lead to over $1 \%$ increase in the Audit fees charged in the examination and investigation of the firm by the professional auditor.

Furthermore, Profit after tax (PAT) which shows a coefficient value of 0.057 with Audit fees (AUDFEES), implies that a unit change in profit after tax of the client's firm can influence the audit fees (AUDFEES) charged on client by $6 \%$. Consequently, client's firm risk (CLFRISK) which has positive coefficient value of 0.289 with audit fees signifies that an increase in firm risk by 0.29 can result to about $29 \%$ increase in audit fees (AUDFEES). However, client's firm complexity (CLFCOMP) whose coefficient value stood at 0.156 with audit fees, shows that a unit increase or change in the extent in which the firm is complex to audit can lead to increase in audit fees (AUDFEES) charged. It is also observed that Audit committee independence with a positive coefficient value of 0.206 with audit fees, implies that a unit change in Audit committee independence can influence decision to change in audit fees by $21 \%$. The coefficient of determination $\mathrm{R}^{2}$ which stood at 0.7206 which shows the systematic variations that occurred and taken between the dependent variable (Audit fees) and the independent variables captured. The implication is that over $72 \%$ of the systematic variations in the dependent variable were explained by the independent variables Auditor Type (AUDTYPE), client's firm size (CLFSIZE), client's firm Profit after tax (CLFPAT), client's firm risk (CLFRISK), client's firm complexity (CLFCOMP) and audit committee independence (AUDCOMIND), while the remaining $28 \%$ were unexplained. Similarly, the adjusted coefficient of determination (adjusted) $\mathrm{R}^{2}$ which occurs as a 
results of the adjustment in the degree of freedom revealed significant value of $0.7142 \mathrm{implies}$ that over $71 \%$ changes in the dependent variable (Audit fees) were accounted for by the independent variables while the remaining $29 \%$ were unaccounted for hence captured by stochastic disturbances and other variables not examined.

Moreover, standard error of regression (S.E Regression) indicates impressive result value of 0.3275 because the lower the value the better the result for judgment. Also, the overall Fstatistics of - fit measure which stood at significant value of 111.68 and P-value of 0.000 suggests the extent in which the results of the panel least square were capable for prediction. This is because the higher the result of the F-statistics than the S.E of regression the better for judgment.

\section{Test of Hypotheses}

The various hypotheses formulated previously in chapter one is tested in this section. The decision rule is that if the calculated P-values is greater than $10 \%$ critical value, we accept the hypothesis otherwise we reject. They are restated and tested as follows: Firstly, hypothesis one stated that Audit firm type does not affect audit fees charged on the client. The outcome in table 4.3 of the t-statistics (1.7582) and P-value stood at $8 \%$ which is less than $10 \%$ critical value, this rightly implies that we reject the null hypothesis, indicating that auditor type significantly affects audit fees (Audfees) charged; secondly, hypothesis two states that client's firm size (Clfsize) does not affect audit fees charged by the auditors. It is observed in table $\mathbf{4 . 3}$ that the t-statistics and P-value stood at 5.3790 and $0 \%$ respectively. Following our decision rule, we therefore reject the null hypothesis, meaning that client's firm size significantly affect audit fees charged by the auditor; thirdly, hypothesis three presented that there is no relationship between client's firm's profitability and audit fees charged. The results of client's firm profitability (Clfpat) against audit fees revealed non-effect in table 4.3, the t-statistics and P-values stood at 1.0881 and 0.2771 (27\%). Based on the decision rule, we therefore accept the null hypothesis as such firms investigated profitability (PAT) has no relationship with audit fees charged by professional auditor; fourthly, it is hypothesized that client's firm risk (clfrisk) does not impact on audit fees. The result in table $\mathbf{4 . 3}$ of the t-statistics and P-values of client's firm risk (Clfrisk) stood at respective values of 9.0123 and $0 \%$, compared to the critical of $P$-value; suggest that firm risk has significant impact on the audit fees charged on the client by the auditors, hence, the null hypothesis is rejected. Fifth, hypothesis five stated that client's firm's complexity does not have effect on audit fees. In table $\mathbf{4 . 3}$ the value of the t-statistics stood at 5.9948 and at P-value of $0 \%$ (less than 10\%). Based on the decision rule, we therefore, reject the null hypothesis, revealing that the complexity of the client's firm has significant effect on audit fees charged by the professional auditors on the clients. Finally, hypothesis six revealed that audit committee independence has no significant relationship with audit fees. But the outcome of the t-statistics and the P-value of (audcomind) in table 4.3 stood at 5.2059 and $0 \%$ respectively. Therefore, based on our decision rule, we reject the null hypothesis, meaning that audit committee independence has a significant impact on audit fees in Nigeria.

\section{Discussion of Findings}

1. Auditor type significantly affects audit fees charged. The audit fees charged by the BIG 4 auditors (KPMG, PriceWater Cooper, Enest and Young, and Akintola Delliotte are far higher than those charge by local auditors. The findings is supported with the views of Choi et al (2010), who 
documented that auditor size or type is positively associated with audit quality, and that large offices attract higher audit fees. Furthermore, Simon (1992) noted that clients pay high audit fees to the international big firms (BIG 4 auditor) like KPMG, PriceWater house Cooper, Earnest and Young and Deloitt. Similarly, Palmrose (1988) also buttressed that strong relationship exist between audit firm type and audit fees, because BIG 4 audit firms receive higher premium fees compared to non BIG 4 audit firms. These differential audit fees charged are attributed to audit firm's size, technology, experience and expertise, quality audit services, financial strengths and numbers of employees available to complete an audit promptly.

2. Audit firm size significantly affects audit fees charged. This is based on the fact that large firms requires or attract more audit work which invariably would attract high audit fees than small size firms. Past studies like Carson, et al (2004); Josh; and Bastaki (2000); Gonthier-Besacier and Schatt (2004), Semiu and Olayinka (2010) and O'Sullivn (2009) evidenced that there is positive correlation and strong relationship between firms' size and audit fees emphasizing that larger organizations usually undertake more voluminous transactions, scope of work, time taken than smaller firms. Despite the views Carson e al (2004) shows that there is no correlation between firm size and audit fees charged by professional auditors.

3. Firm profitability has no relationship with audit fees charged. Issue of profitability (PAT) mostly shows how management performance. Although previous studies have documented that there is positive and negative relationship between profitability (PAT) and audit fees charged (see Joshi et al 2000; Sandra and Patrick, 1996; and Chem et al (2002) suggesting that firms reporting high profit will be subjected to rigorous audit testing.

4. Client risk has significant impact on audit fees. When a firm is financed with debt or leverage, the audit firm is faced with the issue of several documentations and verifications. Again, since the audit firm is expected to do thorough audit work. So as not to tarnish its image, face litigation and adverse press publications, would want to charge high audit fees by properly investigating the extent in which the firm is financed with debt. The finding supports the notion of Simon et al (1987) Craswell and Francis (1999) suggesting that firm risk is positively associated with Audit fees because the more the audit work and time needed to complete the auditing process due to the risk, the higher the audit fees.

5. Firm complexity has significant effect on audit fees charged by the professional auditor. When firm complex in of terms operations, internal control system associated branches and subsidiaries there is tendency that it would attract higher audit fees because of the magnitude of work to be faced by the audit firms. To buttress the finding, Firth (1997); Sandra and Patrick (1996), Carson et al (2004), Semiu and Olayinka (2010) and Francis (1988) established that positive association exists between firm's complexity and audit fees, positing that the complexity of the firm, would require audit of spending longer time and resources in course of examination and investigation of the clients transaction, hence higher audit fees.

6. Audit Committee Independence has a significant impact on audit fees charged by the auditor. This means that, the existence or non-existence of audit committee independence in the client's firm does affect the amount of audit fees. This is a contradiction to the finding of Goddard and Masters (2000) study done in UK's firms that asserted that, the existence of audit committee independence has no significant effect on the amount of audit fees charged by auditors. 


\section{Conclusion}

The separation of ownership from control necessitated the demand of auditor or audit services on the financial statements prepared by client's management. To charge for the engagement of their professional services, the auditors considered several fundamental issues and factors before arriving at their audit fees. Several empirical studies both local and international have proved and evidenced that audit type, auditor's size, client's firm risk and client's firm complexity have significant effect in fixing audit fees which this study quite buttressed.

\section{Recommendations}

1. The audit type should be used as yardstick in fixing in fixing the audit fees. This is based on the notion that, their level of exposure, international affiliations and expertise can have significant influence on the quality of audit services;

2. The client's firm size should be used as a major criterion in the determination of audit fees in Nigeria. Government regulating agencies should see to the issue of audit fees charged by auditors for engaging in audit exercise. It should be clearly reviewed and documented under the section in the Companies and Allied Matters Act that is concerned with the remuneration of the auditors of a firm;

3. The client's firm profitability, audit fees charged by auditors should not be based on profit after tax of client's firm in Nigeria as it does not show any significant effect on audit fees;

4. Client's firm risk, in determining the audit fees by an auditor, firm's risk should be considered in Nigeria because, the length of time that could be used in documentation and tracking of debtors and creditors especially in the banking sector;

5. Clients' firm complexity, the amount of audit fees charged by the auditors should be based on the volumes of work done and the complexity as well. Clients should disclose and informed the auditor of their sphere or scope of operations as is fundamental to the determination of audit fees; and

6. Finally, our result also revealed that audit committee independence has a significant influence on audit fee, hence, it should be considered in determining audit fees.

\section{References}

AICPA, (2012). AU section 312 audit risk and materiality in conducting an audit. http://www.aicpaorg/researchstandards/auditattest/downloadabledocument/AU00312.

Carson, E., Farglier, N., Simon, D. T. \& Taylor, M. H. (2004). Audit fees and market Segmentation-Further evidence on how client size matters within the context of audit Fees models. International Journal of Business Finance and Accounting, 20(6), 765-786.

Chan, P., Ezzamel, M., \& Gwilliam, D. (1993). Determinants of audit fees for Quoted UK companies. Journal of Business Finance and Accounting, 20(6), 76-86.

Che- Ahmed, A., \& Houghton, K. A. (1996). Audit fees premium to big eight firms: evidence from the medium-size UK auditees. Journal of International Accounting, Auditing and Taxation. 5(1), 53-72.

Chung, D. Y., \& Lindsay, W. D. (1998). The pricing of audit services: the Canadian perspective. Contemporary Accounting Research, 5(3), 19-46. 
Choi, Jong-Hag, Kim, Chansog, Kim, Jeong-Bon, \& Zang, Y. (2010). Audit Office Size, Audit Quality, and Audit Pricing. Auditing: A Journal of Practice and Theory, American Accounting Association. 29(1), 73-97.

Collier, P. \& Gregory, A. (1996). Audit committee effectiveness and the audit fees. The European Accounting Review, 5(2), 177-198.

Company and Allied Matter. (2004), as amended.

DeAngelo, L. E. (1981). Auditor size and audit quality. Journal of Accounting and Economics, 3(3), 186-199.

Firth, M. (1985). An analysis of audit fees and their determinants in New Zealand. Auditing a Journal of Practice and Theory 4(2), 23-37.

Geiger, M. A., \& Rama, D. V. (2003). Audit fees, nonaudit fees and auditor reporting on stressed Companies. Auditing: A journal of Practical and Theory.

Gonthier-Besacier, N. \& Schatt, A. (2007). Determinants of audit fees for French Quoted firms. Managerial Auditing Journal, 22 (2), 139-160.

Goddard, A. R \& Masters, C. (2000). Audit committee, Cadbury code and audit fees: An empirical Analysis of UK companies. Managerial Auditing Journal, 15(7), 358-371.

Ho, S. \& Hutchinson, M. (2010). Internal audit department characteristics/activities and audit fees: Some evidence from Hongkong firms, Journal of International Accounting Auditing and Taxation, 19(2), 121-136.

Joshi, P. L., \& Al-Bastaki, H. (2000). Determinants of audit fees: evidence from the companies Listed in Bahrain. International Journal of Auditing, 4(2), 129 138,http://dx.doi.org/10.1111/1099-1123.00308.

Low, L. C., Tan, P. H. N., \& Koh, H. C. (1990). The determinants of audit fees: an analysis in the Singapore context, Journal of Business Finance and Accounting. 17(2), 8595.http://dx.doi.org/10.1111/j.1468-5957,1990.tb00561.x

O'Sullivan, N. (2009). The Impact of Director' and Officers Insurance on Audit Pricing: Evidence from UK Companies, Accounting Forum, 33, 146-161.

Palmrose, Z. V. (1988). An analysis of auditor litigation and audit service quality. The Accounting Research, 63, 55-73.

Rubin, M. A. (1988). Municipal audit fee determinants. The Accounting Review 18(2), 219236.

Sandra, W. M. H., \& Patrick, P. H. N. (1996). The determinants of audit fees in Hong Kong: An Empirical Study, Asian Review of Accounting, 4, 32-50.

Security and Exchange Commission (2001).

Semiu, B. A., \& Olayinka, M. U. (2010). The impact of firms' characteristics on audit fees, Nigeria Journal of Management Studies, 10(2), 4-10.

Simunic, D. A. (1980). The pricing of audit services: Theory and Evidence. Journal of Accounting Research, spring,161190.http://dx.doi.org/10.2307/2490397.

Simon, D. T., Ramanan, R., \& Dugar, A. (1986). The market for audit service in India: an empirical examination. International Journal of Accounting, spring, 27-35.

Simon, D. T., Teo, S., \& Trompeter, G. (1992). A comparative study of the market for audit service in Hong Kong, Malaysia and Singapore. International Journal of Accounting. 27(2), 3440.

Steward, J., \& Munro, L. (2007). The impact of audit committee existence and Audit 
INTERNATIONAL JOURNAL OF ACADEMIC RESEARCH IN BUSINESS AND SOCIAL SCIENCES

Vol. 8, No.3, March 2018, E-ISSN: 2222-6990 C 2018 HRMARS

committee meeting frequency on the external audit: Perceptions of Australian auditors. International Journal of Auditing. 11, 51-69.

Waresulkarim, A. K. M., \& Moizer, P. (1996). Determinants of audit fees in Bangladesh, International Journal of Accounting,31(4), 497509, http://dx.doi.org/10.1016/S00207063(96)90034-5.

Whisenant, S., Sankaraguruswamy, S. \& Raghunandan, k. (2003). Evidence on the joint determination of audit and non- audit fees. Journal of Accounting Research, 41(4), 721744.

Yaro, Y. (1964). The formula for the determination of reasonable sample size of a population. 